Article

\title{
Effect of Bacterial Inoculum and Fertigation Management on Nursery and Field Production of Lettuce Plants
}

\author{
Filippo Vetrano ${ }^{1}$, Claudia Miceli ${ }^{2}{ }^{\circledR}$, Vincenzo Angileri ${ }^{2}$, Benedetto Frangipane ${ }^{2}$, \\ Alessandra Moncada ${ }^{1, *}$ and Alessandro Miceli ${ }^{1, *(D)}$ \\ 1 Dipartimento Scienze Agrarie, Alimentari e Forestali, Università di Palermo, Viale delle Scienze 4, \\ 90128 Palermo, Italy; filippo.vetrano@unipa.it \\ 2 Consiglio per la Ricerca in Agricoltura e l'Analisi dell'Economia Agraria, Centro di ricerca Difesa \\ e Certificazione, 90121 Palermo, Italy; claudia.miceli@crea.gov.it (C.M.); \\ vemanuele.angileri@crea.gov.it (V.A.); benedetto.frangipane@crea.gov.it (B.F.) \\ * Correspondence: alessandra.moncada@unipa.it (A.M.); alessandro.miceli@unipa.it (A.M.); \\ Tel.: +39-09123862232 (A.M.); +39-09123862219 (A.M.)
}

Received: 19 August 2020; Accepted: 25 September 2020; Published: 27 September 2020

\begin{abstract}
Plant growth-promoting rhizobacteria have been applied to different vegetable crops but there is still no information on the effect of bacterial biostimulant application under variable nutritional level on lettuce seedlings and their performance after transplanting in the field. This study aimed to evaluate the efficacy of a bacterial biostimulant to enhance growth and quality of lettuce seedlings fertigated with increasing nutrient rates and to assess the efficacy of these treatments on lettuce head production. Lettuce seedlings were inoculated with $1.5 \mathrm{~g} \mathrm{~L}^{-1}$ of TNC Bactorr $\mathrm{S}^{\mathrm{T}}$ (a commercial biostimulant containing $1.3 \times 10^{8} \mathrm{CFU} \mathrm{g}^{-1}$ of Bacillus spp.) and fertigated with a nutrient solution containing $0,1,2$, and $4 \mathrm{~g} \mathrm{~L}^{-1}$ of NPK fertilizer (20-20-20). At the end of transplant production, the plants were evaluated for greenhouse cultivation. The effect of fertigation rate on seedling height, dry biomass, dry matter percentage, and water use efficiency was evident up to $2 \mathrm{~g} \mathrm{~L}^{-1}$ of fertilizer in the non-inoculated seedlings, whereas fresh biomass and nitrogen use efficiency changed up to $4 \mathrm{~g} \mathrm{~L}^{-1}$ of fertilizer. The use of the bacterial biostimulant modified seedling growth and its response to nutrient availability. The inoculation of the substrate with Bacillus spp. promoted plant growth and allowed seedlings to reach the highest height and biomass accumulation. The physiological age of lettuce seedlings showed a strong influence on plant growth and production after transplanting. The bacterial treatment positively affected the yield and nitrate content of lettuce plants.
\end{abstract}

Keywords: Lactuca sativa; seedling; transplant; plant growth-promoting rhizobacteria; sustainability; biostimulants

\section{Introduction}

The use of vegetable transplants has become common, both for transplanting in open field and under protected cultivation, as it can ensure crop establishment of high-value vegetable crops [1]. Greenhouse, containerized, transplant production for vegetable crops is a standard procedure in many countries of the world [2]. It allows advantages such as reduced cost against direct seeding when using hybrid seeds or grafted plants, easier mulched cultivation, improved land use efficiency, reduction of field occupation time, improved early weed control, enhanced crop earliness, and concentration of crop maturity [3-6]. These advantages are linked to transplant characteristics that may be affected by water and nutrient availability, substrate characteristics and volume, and thermal and light conditions inside the nursery greenhouse [7-13]. The nutrient availability affects seedling growth in the nursery and can 
be used by transplant growers to control transplant quality (optimal size and age for shipment to the market or farmer and for field planting) [14,15]. Thus, the nutritional regime applied to transplants can be managed to modify the production scheduling and seedling characteristics, but also to influence their performance after transplanting [14]. There is a strong bond between the quality of vegetable seedlings and the performance that they will have after transplanting. High fertilization rates during lettuce transplant production positively influence seedling growth and results in higher yields and larger head weight in greenhouse cultivation [16]. So, to reach the goal of producing high-quality lettuce seedlings in a short time with high field performance during crop cultivation, transplant growers often adopt daily applications of water with high concentrations of fertilizers (especially nitrogen) that can run off from the limited substrate volume in the containers, resulting in costly leaching losses and environmental pollution [17]. Today there is a greater environmental and ecological awareness and the number of farmers who want to adopt sustainable and efficient cultivation systems is growing [18]. This awareness has also involved vegetable transplant producers who want to shift from fertilizer and pesticide-based conventional agriculture to natural and renewable resource-based sustainable agriculture, since the latter type is generally cheaper, environment friendly, and draws attention to the conservation of natural resources [19]. The problems of nitrogen pollution, waste runoff, and leaching losses can be partially solved by changing overhead irrigation systems with sub-irrigation systems like the ebb-and-flow system or by supplying encapsulated or controlled-release fertilizers [17]. A sustainable alternative could be represented by the use of biostimulants that can promote plant growth and improve plant quality [20-22]. Among biostimulants, plant growth-promoting rhizobacteria (PGPR) are bacteria naturally occurring in the soil that colonize the rhizosphere and may grow in, on, or around plant roots and benefit plants by increasing plant growth or reducing disease [23,24]. The growth-promoting mechanisms include phytohormone production or hormonal changes within plants, the release of volatile organic compounds, the enhancing of nutrient availability, and the increase of tolerance to biotic and abiotic stresses [24]. PGPR have been applied to different vegetable crops even for transplant production [25-31], but there is still no information on the effect of bacterial biostimulant application under variable nutritional level on lettuce seedlings and their performance after transplanting in the field.

Hence, this study aimed to evaluate the efficacy of a bacterial biostimulant to enhance growth, quality, and establishment success of lettuce seedlings fertigated with increasing nutrient rates and to assess the efficacy of these treatments on lettuce head production.

\section{Materials and Methods}

The effects of fertigation rates and bacterial inoculum of the substrate on transplant production were evaluated with nursery and field trials carried out in a greenhouse situated at the Department of Agricultural, Food, and Forest Sciences (SAAF-University of Palermo, Italy) (38 $06^{\prime} 28^{\prime \prime} \mathrm{N} 13^{\circ} 21^{\prime} 3^{\prime \prime} \mathrm{E}$; altitude $49 \mathrm{~m}$ ) and in a greenhouse-tunnel located at the experimental farm of the Research Unit for Plant Protection and Certification of the Council for Agricultural Research and Economics ( $38^{\circ} 05^{\prime} 00.3^{\prime \prime} \mathrm{N}$ $13^{\circ} 25^{\prime} 24.2^{\prime \prime}$ E; altitude $36 \mathrm{~m}$ ).

\subsection{Plant Materials and Nursery Production}

The nursery production of lettuce seedlings was carried out during autumn 2019 into a greenhouse with fixed benches. Seeds of "Meraviglia d'inverno" lettuce (Blumen, Piacenza, Italy) were sown into 24 polystyrene trays with 160 cells. Twelve trays were filled with a commercial substrate (SER CA-V7 Special semine, Vigorplant Italia srl, Fombio, Italy, fertilized with $800 \mathrm{~g} \mathrm{~m}^{-3}$ of a mineral fertilizer NPK 12-11-18) while the remaining trays were filled with the same substrate inoculated with $1.5 \mathrm{~g}$ $\mathrm{L}^{-1}$ of TNC Bactorr ${ }^{\mathrm{S} 13}$ (The Nutrient Company, Rochdale, UK), a commercial biostimulant containing plant growth-promoting bacteria $\left(1.3 \times 10^{8} \mathrm{CFU} \mathrm{g}^{-1}\right.$ of Bacillus amyloliquefaciens, B. brevis, B. circulans, B. coagulans, B. firmus, B. halodenitrificans, B. laterosporus, B. licheniformis, B. megaterium, B. mycoides, B. pasteurii, B. subtilis, and Paenibacillus polymyxa) as well as soluble humates, natural plant hormones, 
amino acids, vitamins, and trace elements derived from Ascophylum nodosum. After sowing (22 October 2019), all the trays were placed into the greenhouse on benches at a temperature ranging from 18 to $24{ }^{\circ} \mathrm{C}$ and were watered manually every day to maintain the substrate at field capacity. Plantlets emerged 4 days after sowing, and two days after emergence were thinned to one per cell.

Fertilizing treatments started when the plantlets had fully expanded cotyledons and the first true leaf visible ( 7 days after emergence), and were performed by sub-fertigating the trays once a week with four levels of nutrients in the nutrient solution: $0,1,2$, and $4 \mathrm{~g} \mathrm{~L}^{-1}$ of a water-soluble NPK fertilizer (20-20-20). Plantlets were also sub-irrigated according to their necessity until they were ready for transplant (twice a week on average including fertigation). Each tray was weighed before each sub-irrigation and after drainage of the excess water to calculate the amount of water consumed during transplant production. This allowed calculation of the water use efficiency (WUE) as WUE (g DW L ${ }^{-1}$ $\left.\mathrm{H}_{2} \mathrm{O}\right)=$ plant dry weight $(\mathrm{g} \mathrm{DW}) / \mathrm{H}_{2} \mathrm{O}(\mathrm{L})$, and nitrogen use efficiency (NUE) [32] as NUE (g DW g ${ }^{-1}$ $\mathrm{N})$ = plant total dry weight $(\mathrm{g} D W) /$ supplied $\mathrm{N}(\mathrm{g})$ (supplied $\mathrm{N}=$ initial $\mathrm{N}$ content of the substrate $+\mathrm{N}$ supplied with sub-fertigation).

Stomatal conductance was measured (20 days after sowing) with a diffusion porometer (AP4, Delta-T Devices Ltd., Cambridge, England) on two recently expanded unshaded leaves of 20 seedlings for each replicate.

When lettuce seedlings reached the appropriate size for planting (27 days from sowing), four replicated samples of 30 seedlings randomly selected from each treatment were subjected to destructive measurements, where the following parameters were evaluated: plant height, stem diameter, leaf number, leaf color, seedling weight, and leaf area. Seedlings were separated into leaves, stems, and roots, weighed and then dried to constant weight at $85{ }^{\circ} \mathrm{C}$ to determine the fresh and dry biomass. Soon after sampling, leaf color and leaf area of each seedling were determined. Leaf color was measured on the upper part of 2 leaves, randomly selected for each seedling with a colorimeter (CR-400, Minolta corporation, Ltd., Osaka, Japan) that recorded components $L^{*}$ (lightness), $a^{*}$ (positive values for reddish colors and negative values for greenish colors), and $b^{*}$ (positive values for yellowish colors and negative values for bluish colors). These components were used to calculate hue angle $\left(h^{\circ}\right)$ and chroma $\left(\mathrm{C}^{*}\right)$ as $\mathrm{h}^{\circ}=180^{\circ}+\arctan \left(\mathrm{b}^{*} / \mathrm{a}^{*}\right)$ [33] and $\mathrm{C}^{*}=\left(\mathrm{a}^{* 2}+\mathrm{b}^{* 2}\right)^{1 / 2}$. Leaves were then immediately scanned at 350 dpi (Epson Perfection 4180 Photo, Seiko Epson Corp., Suwa, Japan); the digital images were analyzed to measure leaf area with ImageJ 1.52a software (National Institutes of Health, Bethesda, $\mathrm{MD}, \mathrm{USA}$ ). Leaf area and leaf dry weight were used to calculate the specific leaf area (SLA cm${ }^{2} \mathrm{~g}^{-1}$ DW) as leaf area/leaf dry weight.

\subsection{Lettuce Plant Cultivation}

Thirty days after sowing (21 November 2020) lettuce seedlings of each nursery treatment were transplanted, in bare soil (alfisols "Red Mediterranean soils") (11.1 plants $\left.\mathrm{m}^{-2}\right)$ inside a greenhouse tunnel. The treatments were arranged in a randomized complete block design with four replicates (5.4 $\mathrm{m}^{2}$ each). Before transplanting, fertilizers were broadcast $\left(40 \mathrm{~kg} \mathrm{ha}^{-1}\right.$ of $\mathrm{N}, 40 \mathrm{~kg} \mathrm{ha}^{-1}$ of $\mathrm{P}_{2} \mathrm{O}_{5}$, and $40 \mathrm{~kg} \mathrm{ha}^{-1}$ of $\mathrm{K}_{2} \mathrm{O}$ ) and incorporated into the soil. Additional fertilizer was supplied as top dressing 40 days after transplant $\left(40 \mathrm{~kg} \mathrm{ha}^{-1}\right.$ of $\mathrm{N}, 40 \mathrm{~kg} \mathrm{ha}^{-1}$ of $\mathrm{P}_{2} \mathrm{O}_{5}$, and $40 \mathrm{~kg} \mathrm{ha}^{-1}$ of $\left.\mathrm{K}_{2} \mathrm{O}\right)$. During growth, plants were watered according to seasonal needs through a drip irrigation system. All cultural practices recommended for lettuce cultivation were adopted uniformly according to crop requirements.

Harvest started 62 days after transplant and ended within a week according to the effect of seedling treatments on plant growth. At harvest, plants were weighed, and marketable yield was calculated after eliminating the soiled and decayed external leaves. Then, stem diameter, leaf number, leaf color, and plant's fresh and dry weight (drying to constant weight at $85^{\circ} \mathrm{C}$ ) were recorded on 20 randomly selected plants for each replicate. Leaf color was measured on the upper part of 4 leaves, randomly selected for each plant, as described for seedlings.

A representative sample (about $500 \mathrm{~g}$ ) of lettuce leaves (inner, middle, and outer leaves) was collected from five plants for each replicate; leaves were minced and thoroughly mixed and then twenty 
grams of this sample were homogenized with $\mathrm{H}_{2} \mathrm{O}(1: 2 w / v)$ and the homogenates were centrifuged at $3500 \mathrm{rpm}$ for $15 \mathrm{~min}$. The extracts were analyzed to determine the nitrate contents of the leaves (expressed as $\mathrm{mg} \mathrm{kg}^{-1}$ of fresh weight) reflectometrically by a Merck RQflex10 reflectometer according to the company protocols (Merck, Darmstadt, Germany) [34-36].

\subsection{Statistics and Principal Component Analysis}

The experimental layout consisted of four replicates (30 seedlings or 20 plants each) for each combination of seedling treatments and fertilization levels randomly assigned in four blocks. To determine the effect of seedling treatments and fertilization levels on lettuce seedlings ( 30 seedlings for each replicate) and plants (20 plants for each replicate), a two-way ANOVA was carried out. Mean values were compared by the least significant differences (LSD) test at $p \leq 5 \%$ to identify significant differences among treatments and significant differences within the interaction between factors. To define the optimal fertigation rate for plant treatment, a regression analysis was used to fit a linear or second-order polynomial equation to the data of plant parameters evaluated. Statistical significance of the terms in the regression equations was examined by ANOVA for each response.

A principal component analysis was performed with SPSS version 13.0 (SPSS Inc., Chicago, IL, USA) on morphophysiological and yield parameters of seedlings and lettuce plants to study the main parameters that were most effective in discriminating between fertigation levels and bacterial inoculation. The input matrix for the analysis consisted of the main characteristics of seedlings (height, stem diameter, total, shoot and root fresh and dry weight, shoot/root ratio of fresh and dry weights, dry matter percentage, WUE, NUE, leaf number, total leaf area, SLA, stomatal conductance, $\mathrm{L}^{*}$, chroma, and hue angle) and plants (yield, head fresh and dry weight, dry matter percentage, stem diameter, leaf number, $\mathrm{L}^{*}$, chroma, hue angle, and nitrate content). The optimum number of principal components (PCs) was calculated by keeping the factors with eigenvalues higher than 1.0. Besides, the plot of the PCs allowed the study of the correlations between the variables of the input data set. Furthermore, the initial variables were projected into the subspace defined by the first and second PCs, and correlated variables were determined.

\section{Results}

\subsection{Nursery Production of Lettuce Seedlings}

The average temperature outside the greenhouse during the nursery production of lettuce seedlings ranged between $17.8 \pm 0.4$ (night) and $21.4 \pm 0.6{ }^{\circ} \mathrm{C}$ (day), and the average net solar radiation at noon was $449 \mathrm{~W} \cdot \mathrm{m}^{-2}$. The day length during the seedling growth ranged between 7 and $9 \mathrm{~h}$. The highest light intensity inside the greenhouse was 36,919 lux on average, ranging from 55,779 to 4171 lux depending on sky cloudiness. The air temperature inside the greenhouse was on average $24.2 \pm 0.5^{\circ} \mathrm{C}$ and ranged between $15.1 \pm 0.4$ (night) and $31.6 \pm 1.2{ }^{\circ} \mathrm{C}$ (day); relative humidity was $80.8 \%$ on average and ranged between $58.6 \%$ and $98.2 \%$.

Lettuce plantlets emerged 6 days after sowing with no differences between inoculated and not inoculated substrate. Seedlings were ready for transplanting (3-4 true leaves) after $27 \mathrm{~d}$ from sowing.

Seedling height was significantly affected by fertigation following a quadratic trend in both seedling treatments (Figure 1). The bacterial biostimulant increased lettuce seedling growth especially with 1 and $4 \mathrm{~g} \mathrm{~L}^{-1}$ of fertilizer ( $+11.8 \%$ and $+12.6 \%$ than the control, respectively) (Table 1$)$. 


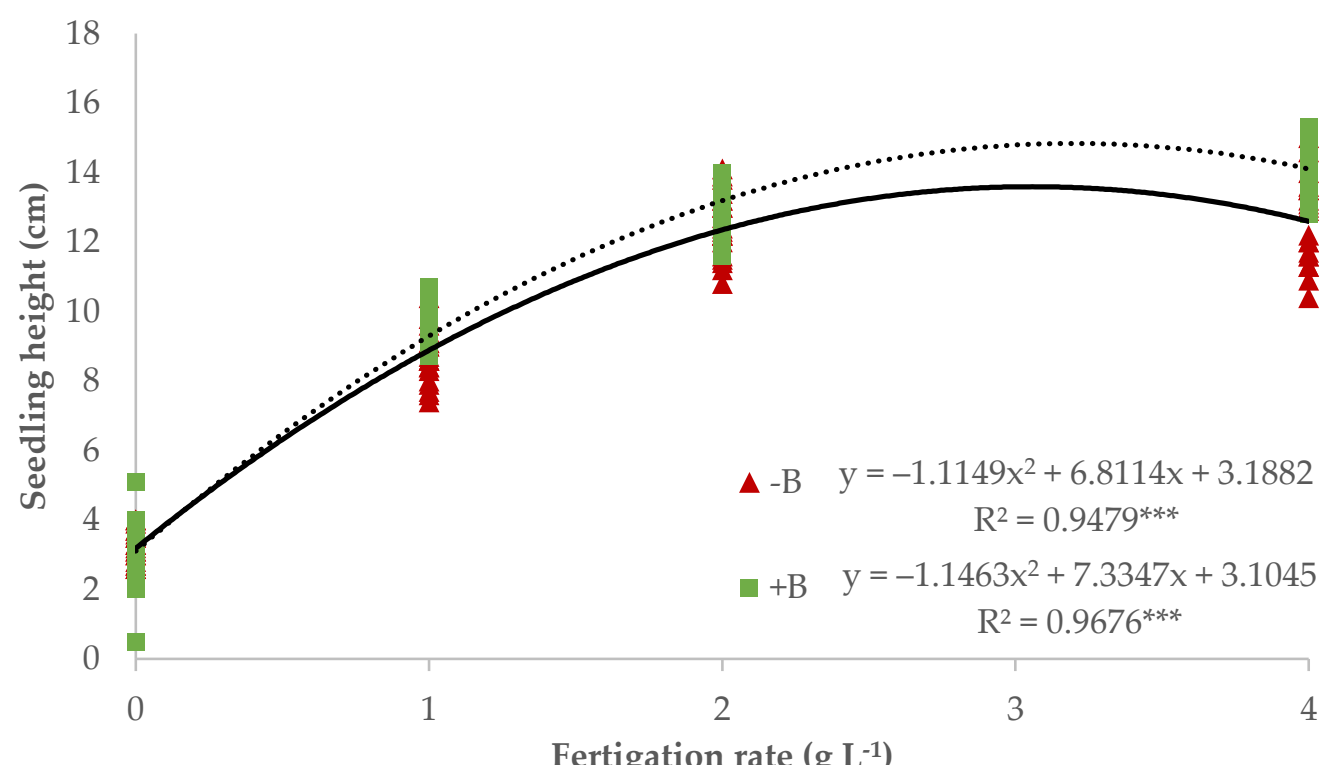

Figure 1. Quadratic predictions of the relationship between fertigation rate ( $\mathrm{g} \mathrm{L}^{-1}$ of NPK 20-20-20) and height values of lettuce seedlings not inoculated (-B, continuous line) or inoculated (+B, dotted line) with a bacterial biostimulant ${ }^{* * *}$ significant at $\left.p<0.001\right)$.

The diameter of the seedling stem did not record significant changes in control plants whereas it was significantly larger in fertigated seedlings than those unfertigated (Table 1).

Lettuce seedlings, both inoculated and not, showed a relationship between the fertigation rate and fresh weight (FW) that fitted a second-order polynomial equation $\left(R^{2}=0.9952\right.$ and 0.9643 for inoculated or uninoculated seedlings, respectively) (Table 1, Figure 2). The lowest accumulation of fresh biomass was recorded in non-fertigated seedlings ( $0.25 \mathrm{~g} \mathrm{FW}$ seedling ${ }^{-1}$, on average). It increased in both seedling treatments but was significantly higher in the inoculated seedlings fertigated with 1 ( $+30.8 \%$ than the control) and $4 \mathrm{~g} \mathrm{~L}^{-1}(+10.6 \%$ than the control) (Table 1$)$.

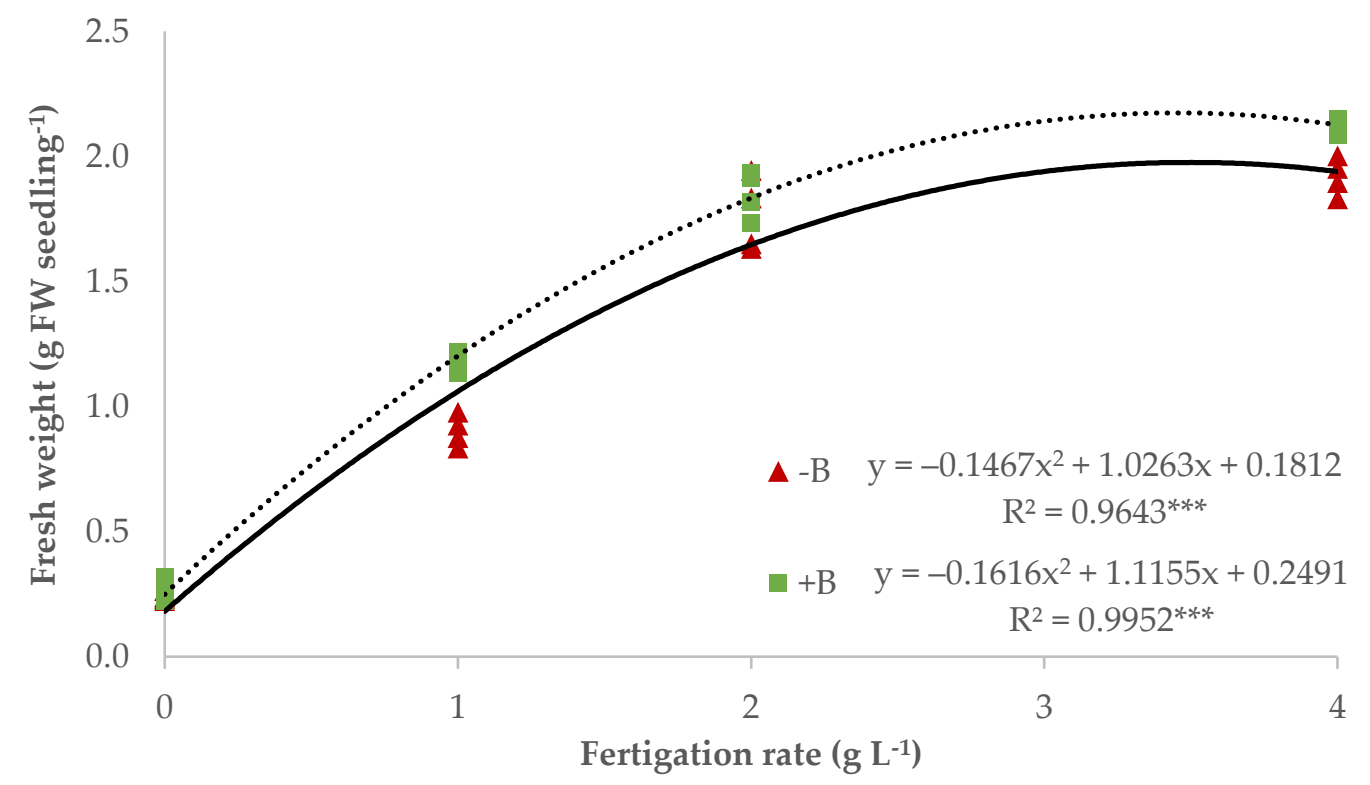

Figure 2. Quadratic predictions of the relationship between fertigation rate ( $\mathrm{g} \mathrm{L}^{-1}$ of NPK 20-20-20) and fresh weight values of lettuce seedlings not inoculated $(-B$, continuous line) or inoculated $(+B$, dotted line) with a bacterial biostimulant (*** significant at $p<0.001)$. 
Table 1. Effects of the bacterial biostimulant (-B, not inoculated; $+\mathrm{B}$, inoculated seedlings) and fertigation rate ( $\mathrm{g} \mathrm{L} \mathrm{L}^{-1}$ of NPK 20-20-20) on morphological and physiological parameters of lettuce seedlings.

\begin{tabular}{|c|c|c|c|c|c|c|c|c|c|c|c|c|c|c|}
\hline \multirow{2}{*}{\multicolumn{2}{|c|}{$\begin{array}{l}\text { Source of } \\
\text { Variance }\end{array}$}} & \multirow{2}{*}{$\begin{array}{c}\text { Plant } \\
\text { Height (cm) }\end{array}$} & \multirow{2}{*}{$\begin{array}{c}\text { Stem } \\
\text { Diameter (mm) }\end{array}$} & \multicolumn{4}{|c|}{ Fresh Weight (g plant ${ }^{-1}$ ) } & \multicolumn{4}{|c|}{ Dry Weight (mg plant ${ }^{-1}$ ) } & \multirow{2}{*}{$\begin{array}{c}\text { Dry } \\
\text { Matter (\%) }\end{array}$} & \multirow{2}{*}{$\begin{array}{c}\text { WUE } \\
\left.\text { (g DW L L }{ }^{-1} \mathrm{H}_{2} \mathrm{O}\right)\end{array}$} & \multirow{2}{*}{$\begin{array}{c}\text { NUE } \\
\left(g^{-1} \text { g g }^{-1} N\right.\end{array}$} \\
\hline & & & & Total & Shoot (S) & Root (R) & $\mathbf{S} / \mathbf{R}$ & Total & Shoot (S) & Root (R) & $\mathbf{S} / \mathbf{R}$ & & & \\
\hline \multicolumn{15}{|c|}{ Bacteria } \\
\hline+ & & z 9.9 & $1.6 \mathrm{a}$ & 1.35 & 1.24 & $0.11 \mathrm{a}$ & 11.4 & 72.2 & $63.0 \mathrm{a}$ & $9.2 \mathrm{~b}$ & 7.7 & 6.6 & 2.6 & 9.6 \\
\hline-1 & & 9.3 & $1.5 \mathrm{a}$ & 1.21 & 1.11 & $0.10 \mathrm{~b}$ & 11.4 & 68.7 & $56.4 \mathrm{~b}$ & $12.3 \mathrm{a}$ & 5.4 & 6.7 & 2.5 & 9.9 \\
\hline \multicolumn{15}{|c|}{$\begin{array}{l}\text { Fertigation } \\
\quad\left(\mathrm{g} \mathrm{L}^{-1}\right)\end{array}$} \\
\hline 0 & & 3.1 & $1.1 \mathrm{~d}$ & 0.25 & 0.19 & $0.06 \mathrm{c}$ & $3.2 \mathrm{a}$ & $34.9 \mathrm{c}$ & $21.9 \mathrm{~d}$ & $13.0 \mathrm{a}$ & 2.0 & $11.8 \mathrm{a}$ & $1.6 \mathrm{c}$ & $20.2 \mathrm{a}$ \\
\hline 1 & & 9.2 & $1.7 \mathrm{c}$ & 1.04 & 0.91 & $0.13 a$ & $6.8 \mathrm{~b}$ & $63.4 \mathrm{~b}$ & $51.8 \mathrm{c}$ & $11.7 \mathrm{ab}$ & 4.9 & $5.7 \mathrm{~b}$ & $2.3 b$ & $8.6 \mathrm{~b}$ \\
\hline 2 & & 12.7 & $1.7 \mathrm{~b}$ & 1.81 & 1.68 & $0.13 a$ & $13.5 c$ & $86.4 \mathrm{a}$ & $76.8 \mathrm{~b}$ & $9.7 \mathrm{ab}$ & 8.2 & $4.6 \mathrm{c}$ & $3.0 \mathrm{a}$ & $6.6 c$ \\
\hline 4 & & 13.4 & $1.6 \mathrm{a}$ & 2.02 & 1.93 & $0.09 \mathrm{~b}$ & $22.1 \mathrm{~d}$ & 97.1a & $88.4 \mathrm{a}$ & $8.7 \mathrm{~b}$ & 11.0 & $4.6 \mathrm{c}$ & $3.2 \mathrm{a}$ & $3.7 \mathrm{~d}$ \\
\hline \multicolumn{15}{|c|}{ Bacteria $\times$} \\
\hline \multicolumn{15}{|c|}{ Fertigation } \\
\hline \multirow[t]{4}{*}{$+\mathrm{B}$} & 0 & $3.0 \mathrm{e}$ & $1.0 \mathrm{c}$ & $0.26 \mathrm{f}$ & $0.20 \mathrm{f}$ & 0.06 & 3.4 & 32.8 & 22.8 & 10.0 & $2.5 \mathrm{c}$ & 11.7 & 1.6 & 19.0 \\
\hline & 1 & $9.7 \mathrm{c}$ & $1.9 \mathrm{a}$ & $1.18 \mathrm{~d}$ & $1.03 \mathrm{~d}$ & 0.15 & 6.8 & 65.3 & 55.3 & 10.0 & $6.0 \mathrm{bc}$ & 5.4 & 2.5 & 9.1 \\
\hline & 2 & $12.9 \mathrm{~b}$ & $1.6 \mathrm{ab}$ & $1.85 \mathrm{bc}$ & $1.72 \mathrm{bc}$ & 0.13 & 13.0 & 89.5 & 79.5 & 10.0 & $8.1 \mathrm{~b}$ & 4.6 & 3.2 & 7.0 \\
\hline & 4 & $14.2 \mathrm{a}$ & $1.6 \mathrm{ab}$ & $2.12 \mathrm{a}$ & $2.03 a$ & 0.09 & 22.4 & 101.2 & 94.5 & 6.7 & $14.1 \mathrm{a}$ & 4.7 & 3.0 & 3.6 \\
\hline \multirow[t]{4}{*}{$-B$} & 0 & $3.3 \mathrm{e}$ & $1.1 \mathrm{bc}$ & $0.24 \mathrm{f}$ & $0.18 \mathrm{f}$ & 0.06 & 3.0 & 37.0 & 21.0 & 16.0 & $1.5 \mathrm{c}$ & 11.8 & 1.5 & 21.4 \\
\hline & 1 & $8.7 \mathrm{~d}$ & $1.5 \mathrm{~b}$ & $0.90 \mathrm{e}$ & $0.79 \mathrm{e}$ & 0.12 & 6.9 & 61.6 & 48.3 & 13.3 & $3.7 \mathrm{c}$ & 6.1 & 2.1 & 8.2 \\
\hline & 2 & $12.5 \mathrm{~b}$ & $1.8 \mathrm{ab}$ & $1.77 \mathrm{c}$ & $1.65 c$ & 0.12 & 14.1 & 83.3 & 74.0 & 9.3 & $8.3 b$ & 4.5 & 2.9 & 6.3 \\
\hline & 4 & $12.6 \mathrm{~b}$ & $1.6 \mathrm{ab}$ & $1.92 \mathrm{~b}$ & $1.84 \mathrm{~b}$ & 0.08 & 21.9 & 92.9 & 82.3 & 10.7 & $8.0 \mathrm{~b}$ & 4.5 & 3.4 & 3.8 \\
\hline \multicolumn{15}{|c|}{ Significance $\mathrm{x}$} \\
\hline \multicolumn{2}{|c|}{ Bacteria } & $* * *$ & ns & $* *$ & $* * *$ & $*$ & ns & ns & ** & $* *$ & $* * *$ & ns & ns & ns \\
\hline \multicolumn{2}{|c|}{ Fertigation } & $* * *$ & $* * *$ & $* * *$ & $* * *$ & $* * *$ & $* * *$ & $* * *$ & $* * *$ & $*$ & $* * *$ & $* * *$ & $* * *$ & $* * *$ \\
\hline \multicolumn{2}{|c|}{$\begin{array}{c}\text { Bacteria } \times \\
\text { Fertigation }\end{array}$} & $* * *$ & $*$ & $* *$ & * & ns & ns & ns & ns & ns & $* *$ & ns & ns & ns \\
\hline
\end{tabular}

${ }^{\mathrm{z}}$ Each value is the mean of 4 replicated samples of 30 seedlings each. For each factor, values in a column followed by different letters are significantly different, according to the LSD test. ${ }^{\mathrm{T}}$

Significance: $\mathrm{ns}=$ not significant; ${ }^{*}$ significant at $p<0.05 ;{ }^{* *}$ significant at $p<0.01 ;{ }^{* * *}$ significant at $p<0.001$. 
A similar trend was found for the shoot fresh weight of the seedlings, whereas the root fresh weight was mainly affected by fertigation rate. The lowest root fresh biomass was recorded in the unfertigated seedlings $\left(0.06 \mathrm{~g} \mathrm{FW} \mathrm{seedling}^{-1}\right)$ and the highest in those fertigated with 1 or $2 \mathrm{~g} \mathrm{~L}^{-1}$ of fertilizer ( $+108.6 \%$ on average); a further increase of fertigation rate reduced root development to $0.09 \mathrm{~g} \mathrm{FW}$ seedling ${ }^{-1}$ (Table 1). Even if the root weight was higher in fertigated seedlings than the control, the fresh weight shoot/root ratio increased linearly $\left(R^{2}=0.968\right)$ from 3.2 up to 22.1.

The total dry weight (DW) of lettuce seedlings varied mainly due to the fertigation rate, following a second-order polynomial equation $\left(R^{2}=0.9269\right)$ with the highest predicted values corresponding to $3.6 \mathrm{~g} \mathrm{~L}^{-1}$ of fertilizer. Nevertheless, the dry biomass accumulated in shoot and roots was affected by both bacterial inoculum and fertigation rate but with an inverse trend in each seedling part (Table 1). The bacterial biostimulant determined an increase of shoot dry weight $(+11.8 \%$ than the control $)$ and a decrease of root dry weight $(-25.7 \%$ than the control). Shoot dry weight determined the main trend found for the total dry weight as it increased according to a quadratic trend $\left(R^{2}=0.9344\right)$ as increasing fertigation rate, whereas the root dry weight slightly but significantly decreased. These effects of bacterial inoculum and fertigation rate resulted in a different modification of dry biomass partitioning between the shoot and roots of the inoculated and uninoculated seedlings as increasing the fertigation rate. This appears evident from the shoot/root ratio that significantly increased from 2.5 to 14.1 with 0 and $4 \mathrm{~g} \mathrm{~L}^{-1}$ of fertilizer in the inoculated seedlings whereas the control seedlings had smaller variations that resulted significantly only with the highest fertigation rates (Table 1). The percentage of dry matter was $11.8 \%$ in the unfertigated seedlings; the lowest fertigation rate $\left(1 \mathrm{~g} \mathrm{~L}^{-1}\right)$ almost halved this parameter (5.7\%) and a further drop was determined with $2 \mathrm{~g} \mathrm{~L}^{-1}$ (4.6\%) (Table 1).

The bacterial biostimulant did not affect the efficiency of the seedlings in using the water and the nitrogen supplied. These parameters varied significantly as a function of the fertigation rate. The WUE recorded the lowest values without fertigation (1.6 g DW L ${ }^{-1} \mathrm{H}_{2} \mathrm{O}$ on average) and reached the highest value in the seedlings fertigated with 2 or $4 \mathrm{~g} \mathrm{~L}^{-1}$ of fertilizer ( $3.1 \mathrm{~g} \mathrm{DW} \mathrm{L}-1 \mathrm{H}_{2} \mathrm{O}$ on average) showing a relationship that fitted a second-order polynomial equation $\left(R^{2}=0.8575\right)$. The unfertigated seedlings showed the highest NUE (20.2 $\mathrm{g} \mathrm{DW} \mathrm{g}^{-1} \mathrm{~N}$, on average); a linear decrease of NUE was found in the fertigated seedlings that ranged from 8.6 to $3.7 \mathrm{~g} \mathrm{DW} \mathrm{g}^{-1} \mathrm{~N}$ with 1 and $4 \mathrm{~g} \mathrm{~L}^{-1}$, respectively.

The number of leaves of lettuce seedlings was influenced significantly by the fertigation rate. The unfertigated seedlings had the lowest leaf number and overcame 3 leaves seedling ${ }^{-1}$ after 27 days from sowing. On the same date, the seedlings fertigated with $1 \mathrm{~g} \mathrm{~L}^{-1}$ of fertilizer had $63.7 \%$ more leaves and those fertigated with 2 or $4 \mathrm{~g} \mathrm{~L}^{-1}$ had almost twice the number of leaves than the control (Table 2). The experimental factor also affected leaf expansion as resulted from the measure of leaf area. The average leaf area was slightly, but not significantly, higher in the inoculated seedlings. A remarkable increase was determined by supplying 1 or $2 \mathrm{~g} \mathrm{~L}^{-1}$ of fertilizer $\left(+6.6\right.$ and $+11.1 \mathrm{~cm}^{2} \mathrm{leaf}^{-1}$ than the control, respectively), but no further increase was recorded with $4 \mathrm{~g} \mathrm{~L}^{-1}$. The small advantage in leaf area of the inoculated seedlings on the single leaf basis determined a significant effect on the total leaf area basis resulting in a greater leaf area $(+10.2 \%)$ than the control seedlings $\left(50.1 \mathrm{~cm}^{2}\right.$ plant $\left.^{-1}\right)$. The seedlings that were not fertigated during nursery growth had a total leaf area of only $6.6 \mathrm{~cm}^{2}$ plant $^{-1}$. The remarkable effect of fertigation on leaf number and leaf area increased up to $44.5 \mathrm{~cm}^{2}$ plant $^{-1}$ and $77.6 \mathrm{~cm}^{2}$ plant ${ }^{-1}$ for the total leaf area of lettuce seedlings fertigated with 1 or $2 \mathrm{~g} \mathrm{~L}^{-1}$ of fertilizer (Table 2). No further significant increase was recorded with the highest fertigation rate. 
Table 2. Effects of the bacterial biostimulant (-B, not inoculated; $+B$, inoculated) and fertigation rate (g L $\mathrm{L}^{-1}$ of NPK 20-20-20) on leaf characteristics of lettuce seedlings.

\begin{tabular}{|c|c|c|c|c|c|c|c|c|c|c|}
\hline $\begin{array}{l}\text { Source of } \\
\text { Variance }\end{array}$ & $\begin{array}{l}\text { Number } \\
\text { of Leaves }\end{array}$ & $\begin{array}{c}\text { Leaf Area } \\
\left(\mathrm{cm}^{2} \text { Seedling }\right. \\
\end{array}$ & $\begin{array}{c}\text { Leaf Area } \\
\left(\mathrm{cm}^{2} \text { Leaf }^{-1}\right)\end{array}$ & $\begin{array}{c}\text { SLA } \\
\left(\mathrm{cm}^{2} \mathrm{~g} \mathrm{DW}^{-1}\right)\end{array}$ & 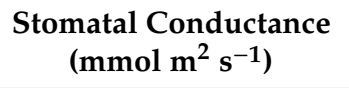 & $\mathbf{L}^{*}$ & $a^{*}$ & $\mathbf{b}^{*}$ & Chroma & Hue $^{\circ}$ \\
\hline \multicolumn{11}{|l|}{ Bacteria } \\
\hline$+\mathrm{B}$ & z 5.1 & $55.2 \mathrm{a}$ & 9.7 & 848.7 & $345.3 a$ & 56.5 & -20.9 & 38.1 & 43.5 & 118.8 \\
\hline$-B$ & 5.0 & $50.1 \mathrm{~b}$ & 9.1 & 849.2 & $275.5 b$ & 56.2 & -21.1 & 37.5 & 43.0 & 119.3 \\
\hline \multicolumn{11}{|l|}{$\begin{array}{l}\text { Fertigation } \\
\left(\mathrm{g} \mathrm{L}^{-1}\right)\end{array}$} \\
\hline 0 & $3.1 \mathrm{c}$ & $6.6 c$ & $2.2 \mathrm{c}$ & $393.2 \mathrm{c}$ & $253.0 \mathrm{~b}$ & $59.2 a$ & $-19.3 a$ & $37.3 b$ & $42.0 \mathrm{c}$ & $117.3 b$ \\
\hline 1 & $5.1 \mathrm{~b}$ & $44.5 b$ & $8.8 \mathrm{~b}$ & $930.1 \mathrm{~b}$ & $273.8 b$ & $56.5 b$ & $-21.8 b$ & $38.5 a$ & $44.2 \mathrm{a}$ & $119.5 a$ \\
\hline 2 & $5.8 \mathrm{a}$ & $77.6 a$ & $13.3 \mathrm{a}$ & $1068.6 a$ & $349.7 \mathrm{ab}$ & $55.2 \mathrm{bc}$ & $-21.4 b$ & $38.1 \mathrm{ab}$ & $43.7 \mathrm{ab}$ & $119.4 a$ \\
\hline 4 & $6.2 \mathrm{a}$ & $81.7 \mathrm{a}$ & $13.2 \mathrm{a}$ & 1003.8ab & $365.2 \mathrm{a}$ & $54.3 \mathrm{c}$ & $-21.5 b$ & $37.2 b$ & $43.0 \mathrm{bc}$ & $120.0 \mathrm{a}$ \\
\hline \multicolumn{11}{|l|}{ Bacteria $\times$} \\
\hline \multicolumn{11}{|l|}{ Fertigation } \\
\hline \multirow{4}{*}{$+\mathrm{B}$} & 3.2 & 6.3 & 2.0 & 370.1 & 317.8 & 59.9 & -18.9 & 37.7 & 42.2 & 116.7 \\
\hline & 5.3 & 49.9 & 9.5 & 980.3 & 285.2 & 56.6 & -21.8 & 39.0 & 44.7 & 119.2 \\
\hline & 6.0 & 79.4 & 13.3 & 1051.0 & 388.4 & 55.6 & -21.3 & 38.3 & 43.9 & 119.1 \\
\hline & 6.1 & 85.0 & 13.9 & 993.5 & 389.8 & 53.8 & -21.7 & 37.2 & 43.0 & 120.3 \\
\hline \multirow[t]{4}{*}{$-B$} & 3.0 & 6.9 & 2.3 & 416.4 & 188.2 & 58.6 & -19.6 & 37.0 & 41.9 & 118.0 \\
\hline & 4.9 & 39.0 & 8.0 & 880.0 & 262.3 & 56.4 & -21.8 & 37.9 & 43.8 & 119.8 \\
\hline & 5.7 & 75.9 & 13.4 & 1086.1 & 310.9 & 54.9 & -21.6 & 37.9 & 43.6 & 119.7 \\
\hline & 6.3 & 78.4 & 12.6 & 1014.2 & 340.6 & 54.7 & -21.3 & 37.2 & 42.9 & 119.8 \\
\hline \multicolumn{11}{|l|}{ Significance ${ }^{x}$} \\
\hline Bacteria & ns & $* *$ & ns & ns & $*$ & ns & ns & ns & ns & ns \\
\hline Fertigation & $* * *$ & $* * *$ & $* * *$ & $* * *$ & * & $* * *$ & $* * *$ & $*$ & $* * *$ & $* * *$ \\
\hline $\begin{array}{l}\text { Bacteria } \times \\
\text { Fertigation }\end{array}$ & ns & ns & ns & ns & ns & ns & ns & ns & ns & ns \\
\hline
\end{tabular}

${ }^{z}$ Each value is the mean of 4 replicated samples of 30 seedlings each. For each factor, values in a column followed by different letters are significantly different, according to the LSD test. ${ }^{~}$

Significance: $\mathrm{ns}=$ not significant; * significant at $p<0.05 ; * *$ significant at $p<0.01 ; * * *$ significant at $p<0.001$. 
Another leaf characteristic that was affected by the fertigation rate was leaf thickness as shown by the increase of the specific leaf area that was $393.2 \mathrm{~cm}^{2} \mathrm{~g}^{-1} \mathrm{DW}$ with $0 \mathrm{~g} \mathrm{~L}^{-1}$ and reached the highest value with $2 \mathrm{~g} \mathrm{~L}^{-1}\left(1068.6 \mathrm{~cm}^{2} \mathrm{~g}^{-1} \mathrm{DW}\right)$.

The experimental factors had a role in modifying leaf physiology as showed by the modification of stomatal conductance. The bacterial biostimulant increased the stomatal conductance of seedling leaves by $25.3 \%$ on average as compared to the control seedling $\left(275.5 \mathrm{mmol} \mathrm{m}^{2} \mathrm{~s}^{-1}\right)$. An increasing trend of this parameter was also due to the fertigation rate but only the highest rate recorded a significant increase $(+44.3 \%)$ compared to the control $\left(253.0 \mathrm{mmol} \mathrm{m}^{2} \mathrm{~s}^{-1}\right)$.

Leaf color varied only as a function of fertigation rates (Table 2). Lettuce leaves get darker as the fertigation level increased as shown by the $\mathrm{L}^{*}$ parameter that dropped from 59.2 to 54.3 for 0 and $4 \mathrm{~g} \mathrm{~L}^{-1}$, respectively; $\mathrm{a}^{*}$ values were lower than the control in all the fertigated seedlings, whereas $\mathrm{b}^{*}$ values were higher than the control only with the lowest fertigation rate $\left(1 \mathrm{~g} \mathrm{~L}^{-1}\right)$. Thus, the leaves had more vivid (higher chroma) color than the control when the seedlings were fertigated with 1 or $2 \mathrm{~g} \mathrm{~L}^{-1}$ of fertilizer and resulted in all the fertigated seedlings being greener (higher hue angle).

\subsection{Lettuce Plants Cultivation}

Lettuce seedlings were transplanted inside a tunnel-greenhouse to evaluate the effects of the experimental factors applied during transplant production on growth and yield of lettuce plants. The temperature inside the greenhouse ranged between the minimum value of 6.7 and the maximum value of $30.8{ }^{\circ} \mathrm{C}$. The average lower temperature was $12.3 \pm 0.4{ }^{\circ} \mathrm{C}$, whereas the average maximum temperature was $23.8 \pm 0.5^{\circ} \mathrm{C}$. Relative humidity ranged between $42.6 \%$ and $95.9 \%$ ( $69.08 \%$ on average). The day length during the cultivation period (from sunrise to sunset) ranged between 7 and $8 \mathrm{~h}$. The highest light intensity at noon inside the greenhouse was 33,366 lux on average, ranging from 55,251 to 3986 lux as a function of the cloudiness.

The plants fertigated in the nursery with 2 or $4 \mathrm{~g} \mathrm{~L}^{-1}$ of fertilizer were ready for harvesting 62 days after transplant, 7 days before the other plants.

Lettuce yield was affected by both experimental factors; the inoculated seedlings yielded $14.0 \%$ more than the control seedlings ( $3.2 \mathrm{~kg} \mathrm{~m}^{-2}$ on average). Yield also increased thanks to the increased fertigation rate during nursery growth and was significantly higher than the control $\left(2.7 \mathrm{~kg} \mathrm{~m}^{-2}\right.$ on average) by supplying 2 or $4 \mathrm{~g} \mathrm{~L}^{-1}$ (3.7 and $4.0 \mathrm{~kg} \mathrm{~m}^{-2}$ on average, respectively) (Table 3).

A similar effect was recorded for the average fresh weight of lettuce heads which increased by $13.0 \%$ due to bacterial inoculum (282.2 $\mathrm{g} \mathrm{FW} \mathrm{plant}^{-1}$ on average for uninoculated seedlings) and by $35.6 \%$ and $46.4 \%$ due to 2 and $4 \mathrm{~g} \mathrm{~L}^{-1}$ of fertilizer, respectively. The fresh weight of lettuce plants showed a relationship with the fertigation rate during transplant production that fitted a second-order polynomial equation $\left(R^{2}=0.8028\right)$ for the non-inoculated plants and a linear equation for the inoculated plants $\left(R^{2}=0.8624\right)$. The dry matter accumulated in lettuce heads grown from uninoculated seedlings was $11.0 \mathrm{~g} \mathrm{DW}_{\text {plant }}{ }^{-1}$ on average, whereas it increased by $17.6 \%$ in those treated with the bacterial biostimulant in the nursery (13.0 $\mathrm{g} \mathrm{DW} \mathrm{plant}^{-1}$ on average) (Table 3). The dry biomass of lettuce heads increased from 10.5 to $13.3 \mathrm{~g} \mathrm{DW} \mathrm{plant}^{-1}$ on average as increasing the nursery fertigation rate from 0 to $4 \mathrm{~g} \mathrm{~L}^{-1}$ (Table 3). The dry weight showed a relationship with the fertigation rate that fitted a second-order polynomial equation for treated and untreated seedlings $\left(R^{2}=0.8339\right.$ and 0.8118 , respectively). The effect of fertigation rate on fresh and dry weight influenced the water content of the lettuce head which increased significantly with the higher nursery fertigation rates $\left(2\right.$ and $\left.4 \mathrm{~g} \mathrm{~L}^{-1}\right)$ as showed by the lower dry matter percentage recorded in these treatments (Table 3).

Other morphological traits of the lettuce plants such as stem diameter and leaf number showed the positive effect of increasing the fertigation rate during nursery growth (Tables 3 and 4). 
Table 3. Effects of the bacterial biostimulant (-B, not inoculated; $+B$, inoculated) and fertigation rate ( $\mathrm{g} \mathrm{L}^{-1}$ of NPK 20-20-20) during transplant production on yield and yield components of lettuce plants grown in a tunnel-greenhouse.

\begin{tabular}{|c|c|c|c|c|c|c|}
\hline $\begin{array}{l}\text { Source of } \\
\text { Variance }\end{array}$ & $\begin{array}{c}\text { Yield } \\
\left(\mathrm{kg} \mathrm{m}^{-2}\right)\end{array}$ & $\begin{array}{l}\text { Fresh Weight } \\
\left.\text { (g plant }^{-1}\right)\end{array}$ & $\begin{array}{l}\text { Dry Weight } \\
\left.\text { (g plant }^{-1}\right)\end{array}$ & $\begin{array}{c}\text { Dry } \\
\text { Matter (\%) }\end{array}$ & $\begin{array}{c}\text { Stem } \\
\text { Diameter }(\mathrm{mm})\end{array}$ & $\begin{array}{c}\mathrm{NO}_{3}^{-} \\
\left(\mathrm{mg} \mathrm{kg}^{-1} \mathrm{FW}\right)\end{array}$ \\
\hline \multicolumn{7}{|l|}{ Bacteria } \\
\hline$+\mathrm{B}$ & z $3.6 a$ & $322.9 a$ & 13.0a & 4.1 & 26.5 & $1853.0 \mathrm{~b}$ \\
\hline$-B$ & $3.2 b$ & $286.2 b$ & $11.0 \mathrm{~b}$ & 3.9 & 25.9 & $2571.7 \mathrm{a}$ \\
\hline \multicolumn{7}{|l|}{$\begin{array}{l}\text { Fertigation } \\
\left(\mathrm{g} \mathrm{L}^{-1}\right)\end{array}$} \\
\hline 0 & $2.7 \mathrm{c}$ & $243.2 \mathrm{c}$ & $10.5 c$ & $4.3 \mathrm{a}$ & $24.2 \mathrm{~b}$ & 2093.6b \\
\hline 1 & $3.1 \mathrm{bc}$ & $286.9 \mathrm{bc}$ & $11.7 \mathrm{~b}$ & $4.1 \mathrm{ab}$ & $25.8 \mathrm{ab}$ & $2102.0 \mathrm{~b}$ \\
\hline 2 & $3.7 \mathrm{ab}$ & $330.7 \mathrm{ab}$ & $12.5 \mathrm{ab}$ & $3.8 \mathrm{~b}$ & $27.4 \mathrm{a}$ & $2155.9 \mathrm{~b}$ \\
\hline 4 & $4.0 \mathrm{a}$ & $357.3 a$ & $13.3 \mathrm{a}$ & $3.7 \mathrm{~b}$ & $27.4 \mathrm{a}$ & $2497.8 \mathrm{a}$ \\
\hline \multicolumn{7}{|l|}{ Bacteria $\times$} \\
\hline \multicolumn{7}{|l|}{ Fertigation } \\
\hline \multirow{4}{*}{$+\mathrm{B}$} & 2.9 & 267.8 & 11.2 & 4.1 & 24.1 & 1819.9 \\
\hline & 3.1 & 281.6 & 12.8 & 4.6 & 25.9 & 1787.2 \\
\hline & 3.9 & 346.6 & 13.2 & 3.8 & 28.6 & 1733.9 \\
\hline & 4.4 & 395.5 & 14.7 & 3.7 & 27.4 & 2070.8 \\
\hline \multirow[t]{4}{*}{$-B$} & 2.4 & 218.5 & 9.9 & 4.5 & 24.4 & 2367.3 \\
\hline & 3.1 & 292.3 & 10.5 & 3.6 & 25.8 & 2416.8 \\
\hline & 3.5 & 314.7 & 11.8 & 3.8 & 26.2 & 2577.9 \\
\hline & 3.5 & 319.2 & 11.9 & 3.7 & 27.4 & 2924.7 \\
\hline \multicolumn{7}{|l|}{ Significance $^{\mathrm{x}}$} \\
\hline Bacteria & * & $*$ & $*$ & ns & ns & $* *$ \\
\hline Fertigation & $* * *$ & $* * *$ & $* * *$ & $* * *$ & $* *$ & $* * *$ \\
\hline $\begin{array}{l}\text { Bacteria } \times \\
\text { Fertigation }\end{array}$ & ns & ns & ns & ns & ns & ns \\
\hline
\end{tabular}

${ }^{\mathrm{z}}$ Each value is the mean of 4 replicated samples of 20 plants each. For each factor, values in a column followed by different letters are significantly different, according to the LSD test. ${ }^{\times}$Significance: $\mathrm{ns}=$ not significant; ${ }^{*}$ significant at $p<0.05 ;{ }^{* *}$ significant at $p<0.01 ;{ }^{* * *}$ significant at $p<0.001$.

Table 4. Effects of the bacterial biostimulant (-B, not inoculated; $+B$, inoculated) and nursery fertigation rate (g L ${ }^{-1}$ of NPK 20-20-20) during transplant production on leaf characteristics of lettuce plants grown in a tunnel-greenhouse.

\begin{tabular}{|c|c|c|c|c|c|c|c|}
\hline \multicolumn{2}{|c|}{ Source of Variance } & Leaf Number & $\mathbf{L}^{*}$ & $a^{*}$ & $\mathbf{b}^{*}$ & Chroma & $\mathrm{Hue}^{\circ}$ \\
\hline \multicolumn{8}{|c|}{ Bacteria } \\
\hline \multicolumn{2}{|c|}{$+\mathrm{B}$} & z 48.1 & 47.6 & $-19.7 a$ & 29.3 & 35.4 & 124.0 \\
\hline \multicolumn{2}{|c|}{$-B$} & 48.0 & 47.6 & $-20.0 b$ & 29.6 & 35.8 & 124.1 \\
\hline \multicolumn{8}{|c|}{$\begin{array}{c}\text { Fertigation } \\
\left(\mathrm{g} \mathrm{L}^{-1}\right)\end{array}$} \\
\hline \multicolumn{2}{|c|}{0} & $43.0 \mathrm{~b}$ & 47.1 & $-19.8 \mathrm{a}$ & $28.6 b$ & $34.8 \mathrm{~b}$ & $124.7 \mathrm{a}$ \\
\hline \multicolumn{2}{|c|}{1} & $47.8 \mathrm{a}$ & 48.5 & $-19.5 a$ & $29.0 \mathrm{~b}$ & $35.0 \mathrm{~b}$ & $124.1 \mathrm{a}$ \\
\hline \multicolumn{2}{|c|}{2} & $49.0 \mathrm{a}$ & 47.3 & $-19.7 \mathrm{a}$ & $29.0 \mathrm{~b}$ & $35.1 b$ & $124.2 \mathrm{a}$ \\
\hline & & $52.4 \mathrm{a}$ & 47.6 & $-20.5 b$ & $31.4 \mathrm{a}$ & $37.5 a$ & $123.2 b$ \\
\hline \multicolumn{8}{|c|}{ Bacteria $\times$ Fertigation } \\
\hline \multirow[t]{4}{*}{$+B$} & 0 & 45.0 & 47.6 & -19.8 & 28.7 & 34.9 & 124.7 \\
\hline & 1 & 46.2 & 47.9 & -19.4 & 28.8 & 34.7 & 124.0 \\
\hline & 2 & 49.5 & 46.9 & -19.3 & 28.1 & 34.1 & 124.5 \\
\hline & 4 & 51.8 & 48.2 & -20.4 & 31.7 & 37.7 & 122.8 \\
\hline \multirow[t]{4}{*}{$-B$} & 0 & 41.0 & 46.6 & -19.7 & 28.6 & 34.7 & 124.6 \\
\hline & 1 & 49.5 & 49.1 & -19.7 & 29.1 & 35.2 & 124.2 \\
\hline & 2 & 48.5 & 47.7 & -20.1 & 29.9 & 36.1 & 123.9 \\
\hline & 4 & 53.0 & 47.0 & -20.6 & 31.0 & 37.2 & 123.6 \\
\hline \multicolumn{8}{|c|}{ Significance $^{\mathrm{x}}$} \\
\hline \multicolumn{2}{|c|}{ Bacteria } & ns & ns & * & ns & ns & ns \\
\hline \multicolumn{2}{|c|}{ Fertigation } & $* * *$ & ns & $* * *$ & $* * *$ & $* * *$ & $* * *$ \\
\hline \multicolumn{2}{|c|}{ Bacteria $\times$ Fertigation } & ns & ns & ns & ns & ns & ns \\
\hline
\end{tabular}

$\mathrm{z}$ Each value is the mean of 4 replicated samples of 20 plants each. For each factor, values in a column followed by different letters are significantly different, according to the LSD test. ${ }^{x}$ Significance: $\mathrm{ns}=$ not significant; ${ }^{*}$ significant at $p<0.05 ;{ }^{* *}$ significant at $p<0.01 ;{ }^{* * *}$ significant at $p<0.001$. 
The nitrate content was $2093.6 \mathrm{mg} \mathrm{kg}^{-1} \mathrm{FW}$ on average in the plants not fertigated during nursery growth. Fertigation determined a significant increase of nitrate content only in the plants that were fertigated in the nursery with $4 \mathrm{~g} \mathrm{~L}^{-1}(+19.3 \%)$. All the plants that were treated with the bacterial biostimulant in the nursery showed a lower nitrate content than the control plants $(-27.9 \%$ on average) (Table 3).

The leaf color of lettuce plants at harvest was affected mainly by nursery fertigation. The highest fertigation rate $\left(4 \mathrm{~g} \mathrm{~L}^{-1}\right)$ determined significant changes in $\mathrm{a}^{*}$ and $\mathrm{b}^{*}$ values so that the leaves had a more vivid but less greenish color (Table 4).

\subsection{Principal Components Analysis}

The results of the principal components analysis showed five principal components (PCs) with eigenvalues higher than 1.00 (Table 5), accounting for $70.71 \%, 10.70 \%, 7.99 \%, 5.16 \%$, and $3.59 \%$ of the total variance, respectively. This indicated that the initial thirty variables could be expressed as a combination of five PCs, explaining $98.15 \%$ of the total variance. PC1 was mainly related to height, stem diameter, total and shoot FW, S/R FW, total DW, shoot DW, root DW, S/R DW, dry matter, WUE, NUE, leaf number, leaf area, SLA, stomatal conductance, $\mathrm{L}^{*}$ and hue angle of the seedlings and yield, fresh and dry weight, dry matter, stem diameter, leaf number, and hue angle of the plants; PC2 was related to the root FW and chroma of the seedling; PC3 was related to the nitrate content of the plants; PC4 was related to the lightness of plant leaf color; and finally, PC5 was mainly related to plant dry matter (Table 5). The projection of the original variables on the plane of the two PCs could demonstrate such a relationship, as shown in the plot of loadings (Figure 3a). The discrimination of the various fertigation rates supplied to lettuce seedlings inoculated or non-inoculated with a bacterial biostimulant can be seen in the plot of scores (Figure 3b), where four clusters could be visibly distinguished. The scores of each fertigation rate were located in a different quadrant of the plane; $0 \mathrm{~g} \mathrm{~L}^{-1}$ was in the third quadrant $(-;-), 1 \mathrm{~g} \mathrm{~L}^{-1}$ was in the second quadrant $(-;+), 2 \mathrm{~g} \mathrm{~L}^{-1}$ was in the first quadrant $(+;+)$, and $4 \mathrm{~g} \mathrm{~L}^{-1}$ was in the fourth quadrant $(+;-)$. The response of lettuce plants inoculated or non-inoculated with the bacterial biostimulant differed for each fertigation rate, as the scores of inoculated lettuce mainly increased their PC1 value by 0 and $4 \mathrm{~g} \mathrm{~L}^{-1}$, whereas it increased their PC2 value with 1 and $2 \mathrm{~g} \mathrm{~L}^{-1}$. Combining the data from the plot of loadings and scores, it can be concluded that fertigation rates influenced the lettuce plants in different ways according to the bacteria inoculum (Figure 3a,b). Fertigation rate was positively related to PC1, whereas the bacteria inoculum was also related to PC2 when combined with 1 or $2 \mathrm{~g} \mathrm{~L}^{-1}$ of fertilizer during transplant production.

Table 5. Correlation of variables to the factors of the principal components analysis (PCA) based on factor loadings.

\begin{tabular}{cccccc}
\hline Variable & PC1 & PC2 & PC3 & PC4 & PC5 \\
\hline Lettuce seedlings & & & & & \\
Height & $\mathbf{0 . 9 9 0}$ & 0.078 & 0.055 & 0.079 & 0.004 \\
Stem diameter & $\mathbf{0 . 7 7 1}$ & 0.532 & 0.198 & 0.012 & 0.249 \\
Total fresh weight & $\mathbf{0 . 9 8 6}$ & -0.041 & 0.000 & 0.150 & 0.023 \\
Shoot fresh weight & $\mathbf{0 . 9 8 3}$ & -0.080 & 0.001 & 0.153 & 0.022 \\
Root fresh weight & 0.476 & $\mathbf{0 . 8 7 5}$ & 0.039 & -0.057 & -0.012 \\
Shoot/Root FW & $\mathbf{0 . 9 0 1}$ & -0.407 & 0.062 & 0.095 & 0.068 \\
Total dry weight & $\mathbf{0 . 9 8 7}$ & -0.060 & 0.039 & 0.125 & 0.008 \\
Shoot dry weight & $\mathbf{0 . 9 9 2}$ & -0.065 & -0.017 & 0.093 & 0.019 \\
Root dry weight & $\mathbf{- 0 . 7 2 4}$ & 0.083 & 0.538 & 0.236 & -0.114 \\
Shoot/Root DW & $\mathbf{0 . 9 2 3}$ & -0.191 & -0.218 & -0.070 & 0.205 \\
Dry matter \% & $\mathbf{- 0 . 9 4 2}$ & -0.280 & -0.175 & -0.017 & 0.038 \\
WUE & $\mathbf{0 . 9 4 3}$ & 0.003 & 0.034 & 0.298 & -0.053 \\
\hline
\end{tabular}


Table 5. Cont.

\begin{tabular}{cccccc}
\hline Variable & PC1 & PC2 & PC3 & PC4 & PC5 \\
\hline NUE & $\mathbf{- 0 . 9 7 1}$ & -0.092 & -0.162 & 0.086 & 0.071 \\
Leaf number & $\mathbf{0 . 9 7 8}$ & 0.119 & 0.095 & 0.095 & -0.040 \\
Leaf area & $\mathbf{0 . 9 8 4}$ & 0.023 & 0.026 & 0.158 & -0.003 \\
SLA & $\mathbf{0 . 9 1 9}$ & 0.332 & 0.189 & 0.066 & -0.011 \\
Stomatal conductance & $\mathbf{0 . 7 7 9}$ & -0.157 & -0.533 & 0.026 & -0.248 \\
L* & $\mathbf{- 0 . 9 6 0}$ & 0.033 & -0.219 & -0.020 & -0.095 \\
Chroma & 0.517 & $\mathbf{0 . 8 4 0}$ & 0.040 & -0.114 & -0.007 \\
Hue & $\mathbf{0 . 8 5 2}$ & 0.111 & 0.421 & -0.131 & 0.109 \\
Lettuce plants & & & & & \\
Yield & $\mathbf{0 . 9 0 2}$ & -0.163 & -0.358 & -0.095 & -0.092 \\
Fresh weight & $\mathbf{0 . 9 1 6}$ & -0.155 & -0.299 & -0.146 & -0.114 \\
Dry weight & $\mathbf{0 . 7 9 1}$ & 0.018 & -0.553 & -0.053 & 0.233 \\
Dry matter \% & -0.623 & 0.343 & -0.178 & 0.227 & $\mathbf{0 . 6 2 8}$ \\
Stem diameter & $\mathbf{0 . 8 8 8}$ & 0.081 & -0.091 & 0.320 & -0.212 \\
Leaf number & $\mathbf{0 . 8 9 7}$ & -0.172 & 0.112 & -0.134 & -0.281 \\
L $^{*}$ & 0.205 & 0.253 & 0.149 & $-\mathbf{0 . 9 2 2}$ & -0.141 \\
Chroma & 0.614 & -0.643 & 0.222 & -0.264 & 0.275 \\
Hue & $\mathbf{0 . 7 8 3}$ & 0.318 & -0.079 & 0.311 & -0.413 \\
Nitrate content & 0.163 & -0.437 & $\mathbf{0 . 8 6 2}$ & 0.101 & -0.007 \\
\hline
\end{tabular}

Values in bold within the same factor indicate the variable with the largest correlation.

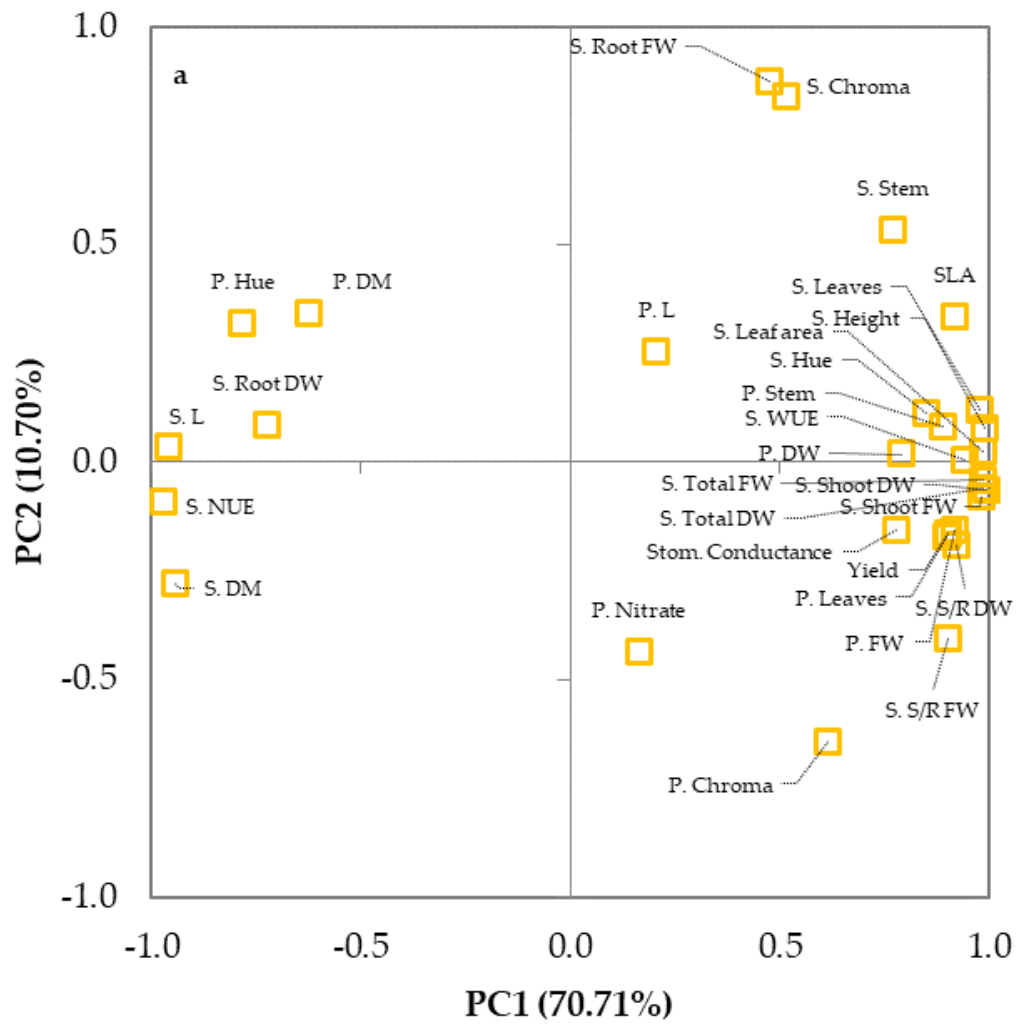

Figure 3. Cont. 


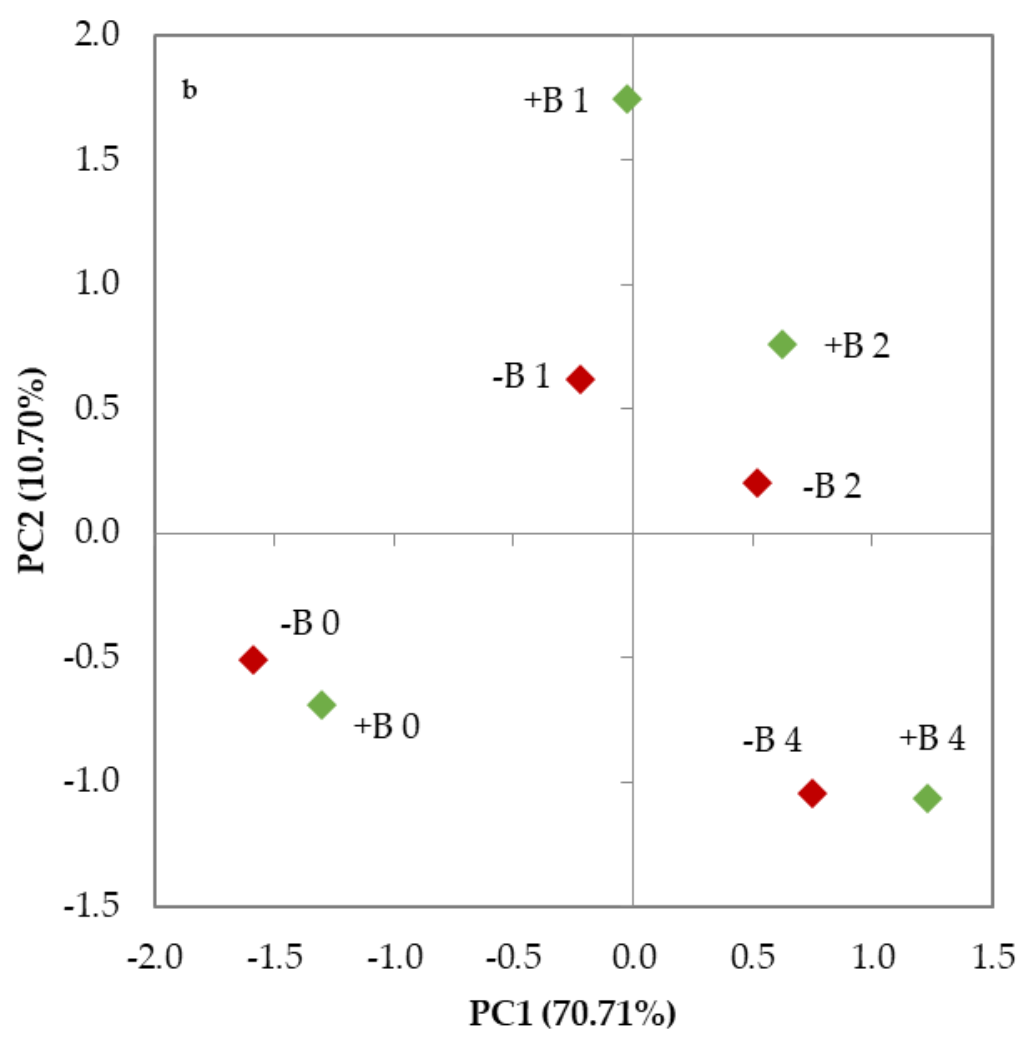

Figure 3. Plot of (a) loadings (morphophysiological and quality characteristics of lettuce seedlings and plants) and (b) scores (trials) formed by the two principal components from the PCA analysis. -B 0, -B 1, -B 2, and -B 4: uninoculated lettuce fertigated during nursery growth with $0,1,2$, and $4 \mathrm{~g} \mathrm{~L}^{-1}$ of fertilizer, respectively; + B $0,+B 1,+B 2$, and + B 4 : inoculated lettuce fertigated during nursery growth with $0,1,2$, and $4 \mathrm{~g} \mathrm{~L}^{-1}$ of fertilizer, respectively.

\section{Discussion}

The goal of the nursery vegetable industry is to produce strong, vigorous compact plug plants with fast establishment and growth when transplanted in the field so that they can give optimum yield and high quality [25]. Many factors need to be well managed to reach this goal (water and nutrient availability, substrate characteristics and volume, and thermal and light conditions inside the nursery greenhouse) [7-13], but nitrogen availability, above all, may strongly affect seedling growth in the greenhouse and could have a long term effect on the growth in the field after transplanting [10,15]. Thus, the careful management of nutrient supply to seedlings can lead to improvements in seedling vigor and establishment in the field and reduction of leaching risks and environmental pollution. In our work, we combined the use of plant growth-promoting bacteria to different levels of seedling nutrition to achieve improved seedling quality and lettuce production after the transplant in the field. The experimental factors interacted and showed the opportunity of modifying the seedling response to nutrient supplementation and the growth and yield of lettuce plants after transplanting.

The results confirmed that the nutrient levels supplied to lettuce seedlings can influence their growth and vigor. The main growth parameters increased quadratically in response to nitrogen, phosphorus, and potassium increase, with the highest values predicted in the range between 3 and $4 \mathrm{~g} \mathrm{~L}^{-1}$ of fertilizer. Thus, overfertilization could be harmful to lettuce seedling quality and the environment $[8,10,15,25,37]$. The increase of water and fertilizer supply can influence seedling growth, but taller seedlings are often weaker and softer and more susceptible to diseases, insects, and transplant shock $[13,37]$. Some characteristics of the seedling are linked to their vigor and the subsequent success of the transplants in the field and can vary according to vegetable species. Many vegetable transplants should be short and stocky to allow greater greenhouse space efficiency and to improve the ease in 
shipment and mechanical transplanting [14]. Nevertheless, well-developed transplants with a higher biomass content and leaf number can shorten the time from transplanting to production and have a positive effect on yield and quality of lettuce [37].

The effect of fertigation rate on seedling height, dry biomass, dry matter percentage, and WUE was evident up to $2 \mathrm{~g} \mathrm{~L}^{-1}$ of fertilizer in the non-inoculated plug plants, whereas fresh biomass and NUE increased to $4 \mathrm{~g} \mathrm{~L}^{-1}$ of fertilizer. The use of bacterial biostimulant modified seedling growth and its response to nutrient availability. The inoculation of the substrate with Bacillus spp. promoted plant growth and allowed seedlings to reach the highest height and biomass accumulation. Many Bacillus species have been studied for their plant growth-promoting effect [38-40]. The multiplication and metabolic activity of these rhizobacteria can be affected by nutrient availability that can also influence the growth of roots and their interaction with bacteria [41-43]. In some soil conditions, as in the case of the sowing substrate, the lack of organic $C$ materials from active plant roots represent a limiting factor for rhizosphere microflora [44] that can also be linked with vegetable species. Thus, the nutrients available to seedlings and high bacteria population of the inoculated substrate can interfere with plant growth and biomass accumulation and limit or enhance plant growth-promoting effect [45]. This interaction may have determined the different responses of seedlings to the Bacillus spp. at different levels of nutrients supplied by fertigation as highlighted by the principal component analysis. PCA showed a greater modification of some growth parameters with 1 and $2 \mathrm{~g} \mathrm{~L}^{-1}$ in the inoculated seedlings that shown to have a more efficient use of the highest nutrient supplementation with a higher increase of PC1 values.

The Bacillus inoculum improved root development in terms of fresh weight but these roots had a lower content of dry biomass. This explains the modifications of biomass partitioning that were due to the bacterial inoculum only on a dry matter basis, as showed by the shoot/root dry weight ratio. Increasing substrate fertility causes a reduction of root growth relative to shoot growth [37,46,47]. Root growth is very important to reduce field transplant loss as it is related to pulling success (transplants that are pulled from the trays with no stem breakage and intact root system) [37].

Plant growth promotion resulting from the bacterial biostimulant application could be due to different mechanisms. Some PGPR exert their positive effects on plants through their ability to produce phytohormones, while others are known to increase the availability of mineral nutrients for plants $[40,48,49]$. The content of endogenous hormones (auxins, and cytokinins) can increase in lettuce plants treated with Bacillus subtilis [48]. Plant hormones are involved in the control of plant growth and development, thus the increase of hormone content could explain the modifications recorded in the inoculated lettuce seedlings. The effect of PGPR on phytohormones content in plants can be direct, as a consequence of the production of phytohormones by bacteria, or indirect due to the increase of mineral nutrient availability caused by the microorganisms [50]. Arkhipova et al. [48] suggested that to have a measurable growth response in the plants, microorganisms must produce and accumulate some metabolites in the rhizosphere. These metabolites could be cytokinins, as found for Bacillus subtilis, or other phytohormones, as found for other Bacillus spp. and other PGPR $[40,48,51]$. Their production could be related to nutrient availability in the substrate that influences bacterial metabolism as well as plant growth. This could also explain the different response of seedlings to the Bacillus spp. inoculum at different fertigation rates.

The increased growth rate determined by the bacterial inoculum could allow producing well-developed transplants in less time or with less fertilizer than is needed without bacterial biostimulant [25]. Moreover, the increase of the vigor and shoot weight of plug plants determines a reduction of transplant shock, an increase of drought tolerance, and greater resistance to biotic stress [52].

We also found that bacterial inoculum increased the total leaf area of the seedlings and the stomatal conductance of their leaves. Thus, the higher biomass accumulation could be due to the greater photosynthetic area and to the increased $\mathrm{CO}_{2}$ availability through the open stomata. Plan growth-promoting bacteria can enhance transpiration along with an increase of photosynthetic 
rate [53-56], which could explain increases in dry matter accumulation and WUE. Moreover, the increased photosynthetic activity caused by plant growth-promoting rhizobacteria can be a consequence of stimuli effects on chlorophyll formation [54,57], but in our experiment, there was no significant modification of leaf color due to bacterial inoculum that can indicate changes in leaf pigment content $[35,58,59]$ as the only modifications were due to the fertigation rate.

As already stated, transplant characteristics are important for their commercial quality and for a fast recovery after transplanting. The physiological age of the seedlings and the growth conditions that they undergo during their first weeks may affect the future yields of vegetable crops $[10,15,60]$.

The physiological age of lettuce seedlings showed a strong influence on plant growth and production after transplanting. Plant fresh weight and yield were positively related to the stem diameter and leaf number of lettuce transplants. Thus, all the growth and quality parameters were influenced by the fertigation rate during seedling growth, whereas only biomass accumulation and nitrate content were influenced by the bacterial treatment of seedlings. This evidence might suggest that transplant substrate could be the vector for the bacterial inoculum of the soil in which seedlings are transplanted, extending the beneficial effect of PGPR from nursery to field. Nevertheless, further experiments should be performed to confirm this hypothesis. Pretransplanting fertilization with nitrogen, phosphorus, and potassium can positively influence lettuce growth in the field by hastening maturity and increasing yield, head weight, and head quality $[37,46,47]$, as also found in our greenhouse cultivation experiment. Lettuce yield and quality were related to plug plant characteristics at transplanting. The head weight at harvest showed to be linearly related to fresh and dry biomass, leaf number, and total leaf area of the seedling transplanted in the field. The positive effects of the fertigation during transplant production were enhanced by the bacterial biostimulant applied to the seedlings which further increased yield and head weight and significantly reduced the nitrates accumulated in the leaves. The nitrate content of lettuce leaves did not exceed the maximum level imposed by the European Commission (EC Reg. No. 1258/2011) for protected-grown lettuce (5000 $\mathrm{mg} \mathrm{kg}^{-1} \mathrm{FW}$ ) harvested from October 1st to March 31st [61], but a lower nitrate content, as found for inoculated lettuce, can be healthier for consumers. A reduction of the nitrate content was also found in baby leaf lettuce grown in a floating system where Bacillus velezensis was added in the nutrient solution [62] and in tomato and spinach grown in soil amended with strains of Bacillus subtilis and Bacillus mucilaginosus [63]. This effect of PGPR on nitrate accumulation is still not clear but it seems it can involve the process of nitrate assimilation initiated by nitrate reductase, as PGPR can significantly influence the nitrate reductase activity in field conditions [64]. The influence of PGPR could be mediated by their phytohormone production, especially regarding gibberellins. Gibberellins affect nitrogen metabolism and nitrogen translocation in plants by improving utilization of $\mathrm{N}$ through increased nitrate reductase activity $[65,66]$, resulting in increased yield and lower nitrate accumulation [67-70]. Another response of plants to inoculation with PGPR is the increased accumulation of chlorophyll and carotenoids [48], but in our study, the only significant effect of the bacterial biostimulant was recorded in the $\mathrm{a}^{*}$ values of lettuce leaves showing that there was no significant modification of leaf pigments as a function of bacterial inoculum, whereas leaves were affected by the highest fertigation rate during transplant production as they had a more vivid but less greenish color.

\section{Conclusions}

Fertigation influenced all the growth and quality characteristics of lettuce seedlings and showed its greatest effect in the range $2-4 \mathrm{~g} \mathrm{~L}^{-1}$ of a $20-20-20$ NPK water-soluble fertilizer. The bacterial biostimulant enhanced transplant growth during nursery production and this could allow the production of the transplant in less time or reducing the fertigation rate of about $1 \mathrm{~g} \mathrm{~L}^{-1}$ without affecting plant growth compared to non-inoculated transplant. The improvements in seedling growth due to fertigation allowed lettuce plants grown in protected cultivation to increase yield and quality even if the highest fertigation rate increased the accumulation of nitrates in the leaves. The transplants inoculated with 
the bacterial biostimulant extended the beneficial effect of PGPR from nursery to field with increased crop yield and biomass accumulation and lower nitrate content.

Author Contributions: Conceptualization, F.V., C.M., A.M. (Alessandra Moncada) and A.M. (Alessandro Miceli); Data curation, V.A., B.F. and A.M. (Alessandro Miceli); Formal analysis, F.V., C.M. A.M. (Alessandra Moncada) and A.M. (Alessandro Miceli); Investigation, F.V., C.M., V.A., B.F., A.M. (Alessandra Moncada) and A.M. (Alessandro Miceli); Methodology, F.V., C.M., A.M. (Alessandra Moncada) and A.M. (Alessandro Miceli); Supervision, C.M. and A.M. (Alessandro Miceli); Validation, F.V., A.M. (Alessandra Moncada) and A.M. (Alessandro Miceli); writing-original draft, F.V., A.M. (Alessandra Moncada) and A.M. (Alessandro Miceli); writing-review and editing, C.M., A.M. (Alessandra Moncada) and A.M. (Alessandro Miceli). All authors have read and agreed to the published version of the manuscript.

Funding: This research received no external funding.

Conflicts of Interest: The authors declare no conflict of interest.

\section{References}

1. Sterrett, S. Composts as Horticultural Substrates for Vegetable Transplant Production. In Compost Utilization in Horticultural Cropping Systems; Stoffella, P.J., Kahn, B.A., Eds.; Lewis Publication: Boca Raton, FL, USA, 2001; pp. 227-240. ISBN 1420026224.

2. Nicola, S.; Cantliffe, D.J. Increasing Cell Size and Reducing Medium Compression Enhance Lettuce Transplant Quality and Field Production. HortScience 1996, 31, 184-189. [CrossRef]

3. Iapichino, G.; Vetrano, F.; Moncada, A.; Fascella, S.; Incalcaterra, G. Effects of plastic mulch and floating cover on lettuce production in sicily. Acta Hortic. 2012, 936, 491-494. [CrossRef]

4. Kubota, C.; McClure, M.A.; Kokalis-Burelle, N.; Bausher, M.G.; Rosskopf, E.N. Vegetable Grafting: History, Use, and Current Technology Status in North America. HortScience 2008, 43, 1664-1669. [CrossRef]

5. Caracciolo, G.; Moncada, A.; Prinzivalli, C.; D'Anna, F. Effects of thr plantinig dates on strawberry plug plant performance in sicly. Acta Hortic. 2009, 155-158. [CrossRef]

6. Swiader, J.M.; Ware, G.W.; McCollum, J.P. Producing Vegetable Crops: Teacher's Manual; Interstate Publishers: Crete, IL, USA, 1992; ISBN 0813429048.

7. Herrera, F.; Castillo, J.; Chica, A.; Bellido, L.L. Use of municipal solid waste compost (MSWC) as a growing medium in the nursery production of tomato plants. Bioresour. Technol. 2008, 99, 287-296. [CrossRef] [PubMed]

8. Russo, V.M. Biological amendment, fertilizer rate, and irrigation frequency for organic Bell pepper transplant production. HortScience 2006, 41, 1402-1407. [CrossRef]

9. McCall, D. Effect of supplementary light on tomato transplant growth, and the after-effects on yield. Sci. Hortic. 1992, 51, 65-70. [CrossRef]

10. Masson, J.; Tremblay, N.; Gosselin, A. Nitrogen Fertilization and HPS Supplementary Lighting Influence Vegetable Transplant Production. I. Transplant Growth. J. Am. Soc. Hortic. Sci. 1991, 116, 594-598. [CrossRef]

11. Masson, J.; Tremblay, N.; Gosselin, A. Effects of Nitrogen Fertilization and HPS Supplementary Lighting on Vegetable Transplant Production. II. Yield. J. Am. Soc. Hortic. Sci. 1991, 116, 599-602. [CrossRef]

12. Miceli, A.; Romano, C.; Vetrano, F.; D'Anna, F. Effects of a Brassica juncea cover crop on a mono-succession of melon. Acta Hortic. 2013, 447-451. [CrossRef]

13. Schrader, W.L. Using Transplants in Vegetable Production; University of California Agriculture and Natural Resources (UC ANR): St. Davis, CA, USA, 2000.

14. Dufault, R.J. Vegetable Transplant Nutrition. HortTechnology 1998, 8, 515-523. [CrossRef]

15. Liptay, A.; Nicholls, S. Nitrogen Supply during Greenhouse Transplant Production Affects Subsequent Tomato Root Growth in the Field. J. Am. Soc. Hortic. Sci. 1993, 118, 339-342. [CrossRef]

16. Vetrano, F.; Iapichino, G.; Poma, M.; Fascella, S.; Incalcaterra, G. Use of organic fertilizers for lettuce plug plant production. Acta Hortic. 2009, 607-612. [CrossRef]

17. Chen, J.; Huang, Y.; Caldwell, R.D. Best Management Practices for Minimizing Nitrate Leaching from Container-Grown Nurseries. Sci. WorldJ. 2001, 1, 96-102. [CrossRef] [PubMed]

18. Moncada, A.; Miceli, A.; Vetrano, F. Use of plant growth-promoting rhizobacteria (PGPR) and organic fertilization for soilless cultivation of basil. Sci. Hortic. 2020, 275, 109733. [CrossRef] 
19. Shereni, C. Use of Biostimulants as an Alternate Approach to Achieve Plant Performance and Fruit Quality, Stellenbosch; Stellenbosch University: Cape Town, South Africa, 2019.

20. Bashan, Y.; De-Bashan, L.E.; Prabhu, S.R.; Hernandez, J.-P. Advances in plant growth-promoting bacterial inoculant technology: Formulations and practical perspectives (1998-2013). Plant Soil 2014, 378, 1-33. [CrossRef]

21. Calvo, P.; Nelson, L.; Kloepper, J.W. Agricultural uses of plant biostimulants. Plant Soil 2014, $383,3-41$. [CrossRef]

22. Du Jardin, P. Plant biostimulants: Definition, concept, main categories and regulation. Sci. Hortic. 2015, 196, 3-14. [CrossRef]

23. Glick, B.R. The enhancement of plant growth by free-living bacteria. Can. J. Microbiol. 1995, 41, $109-117$. [CrossRef]

24. Ruzzi, M.; Aroca, R. Plant growth-promoting rhizobacteria act as biostimulants in horticulture. Sci. Hortic. 2015, 196, 124-134. [CrossRef]

25. Kloepper, J.; Reddy, M.; Rodríguez-Kábana, R.; Kenney, D.; Kokalis-Burelle, N.; Martinez-Ochoa, N.; Vavrina, C.S. Application for Rhizobacteria in transplant production and yield enhancement. Acta Hortic. 2004, 631, 219-229. [CrossRef]

26. Gul, A.; Kidoglu, F.; Tüzel, Y.; Tüzel, I.H. Effects of nutrition and "Bacillus amyloliquefaciens" on tomato ("Solanum lycopersicum L.") growing in perlite. Span. J. Agric. Res. 2008, 6, 422-429. [CrossRef]

27. Akram, W.; Anjum, T.; Ali, B. Co-cultivation of tomato with two Bacillus strains: Effects on growth and yield. J. Anim. Plant Sci. 2015, 25, 1644-1651.

28. Kokalis-Burelle, N.; Vavrina, C.S.; Rosskopf, E.N.; Shelby, R.A. Field evaluation of plant growth-promoting Rhizobacteria amended transplant mixes and soil solarization for tomato and pepper production in Florida. Plant Soil 2002, 238, 257-266. [CrossRef]

29. Kokalis-Burelle, N.; Vavrina, C.; Reddy, M.; Kloepper, J. Amendment of Muskmelon and Watermelon Transplant Media with Plant Growth-Promoting Rhizobacteria: Effects on Seedling Quality, Disease, and Nematode Resistance. HortTechnology 2003, 13, 476-482. [CrossRef]

30. Yan, Z.; Reddy, M.S.; Kloepper, J.W. Survival and colonization of rhizobacteria in a tomato transplant system. Can. J. Microbiol. 2003, 49, 383-389. [CrossRef]

31. Ekinci, M.; Turan, M.; Yildirim, E.; Güneş, A.; Kotan, R.; Dursun, A. Effect of plant growth promoting rhizobacteria on growth, nutrient, organic acid, amino acid and hormone content of cauliflower (Brassica oleracea L. var. botrytis) transplants. Acta Sci. Pol. Hortorum Cultus 2014, 13, 71-85.

32. Fageria, N.K.; Baligar, V.C.; Li, Y. The Role of Nutrient Efficient Plants in Improving Crop Yields in the Twenty First Century. J. Plant Nutr. 2008, 31, 1121-1157. [CrossRef]

33. Miceli, C.; Moncada, A.; Vetrano, F.; Iapichino, G.; D'Anna, F.; Miceli, A. Effect of Agronomic Practices on Yield and Quality of Borage at Harvest and During Storage as Minimally-Processed Produce. Agronomy 2020, 10, 242. [CrossRef]

34. Rodrigo, M.C.; Ramos, C. Nitrate sap analysis as a tool to assess nitrogen nutrition in artichoke. In Proceedings of the VI International Symposium on Artichoke, Cardoon and Their Wild Relatives 730, Lorca, Spain, 28-31 March 2006; pp. 251-256.

35. Miceli, A.; Miceli, C. Effect of Nitrogen Fertilization on the Quality of Swiss Chard at Harvest and during Storage as Minimally Processed Produce. J. Food Qual. 2014, 37, 125-134. [CrossRef]

36. Caracciolo, G.; D'Anna, E.; Moncada, A.; D'Anna, F. Evaluation of the quality and antioxidant capacity of woodland strawberry biotypes in Sicily. J. Food Agric. Environ. 2013, 11, 522-525.

37. Soundy, P.; Cantliffe, D.J.; Hochmuth, G.J.; Stoffella, P.J. Management of Nitrogen and Irrigation in Lettuce Transplant Production affects Transplant Root and Shoot Development and Subsequent Crop Yields. HortScience 2005, 40, 607-610. [CrossRef]

38. Sahin, F.; Cakmakci, R.; Kantar, F. Sugar beet and barley yields in relation to inoculation with N2-fixing and phosphate solubilizing bacteria. Plant Soil 2004, 265, 123-129. [CrossRef]

39. Shao, J.; Xu, Z.; Zhang, N.; Shen, Q.; Zhang, R. Contribution of indole-3-acetic acid in the plant growth promotion by the rhizospheric strain Bacillus amyloliquefaciens SQR9. Boil. Fertil. Soils 2014, 51, 321-330. [CrossRef] 
40. Joo, G.-J.; Kim, Y.-M.; Lee, S.-U.; Song, K.-S.; Rhee, I.-K. Growth promotion of red pepper plug seedlings and the production of gibberellins by Bacillus cereus, Bacillus macroides and Bacillus pumilus. Biotechnol. Lett. 2004, 26, 487-491. [CrossRef]

41. Ekin, Z.; Faruk, O.; Erman, M.; Erdal, Ö. The effect of Bacillus sp. OSU-142 inoculation at various levels of nitrogen fertilization on growth, tuber distribution and yield of potato (Solanum tuberosum L.). Afr. J. Biotechnol. 2009, 8, 4418-4424.

42. Welbaum, G.E.; Sturz, A.V.; Dong, Z.; Nowak, J. Managing Soil Microorganisms to Improve Productivity of Agro-Ecosystems. Crit. Rev. Plant Sci. 2004, 23, 175-193. [CrossRef]

43. Marschner, P.; Gerendás, J.; Sattelmacher, B. Effect of N concentration and N source on root colonization by Pseudomonas fluorescens 2-79RLI. Plant Soil 1999, 215, 135-141. [CrossRef]

44. Rovira, A.D.; Davey, C.B. Biology of the rhizosphere. In The Plant Root and its Environment; Carson, E., Ed.; University of Virginia Press: Charlottesville, VR, USA, 1974; ISBN 978-0813904115.

45. Oliveira, A.L.M.; Urquiaga, S.; Döbereiner, J.; Baldani, J. The effect of inoculating endophytic N2-fixing bacteria on micropropagated sugarcane plants. Plant Soil 2002, 242, 205-215. [CrossRef]

46. Soundy, P.; Cantliffe, D.J.; Hochmuth, G.J.; Stoffella, P.J.; Hall, F.; Box, P.O. Nutrient Requirements for Lettuce Transplants Using a Floatation Irrigation System II. Potassium. HortScience 2001, 36, 1071-1074. [CrossRef]

47. Soundy, P.; Cantliffe, D.J.; Hochmuth, G.J.; Stoffella, P.J.; Hall, F.; Box, P.O. Nutrient Requirements for Lettuce Transplants Using a Floatation Irrigation System. I. Phosphorus. HortScience 2001, 36, 1066-1070. [CrossRef]

48. Arkhipova, T.N.; Veselov, S.U.; Melentiev, A.I.; Martynenko, E.V.; Kudoyarova, G.R. Ability of bacterium Bacillus subtilis to produce cytokinins and to influence the growth and endogenous hormone content of lettuce plants. Plant Soil 2005, 272, 201-209. [CrossRef]

49. Ping, L.; Boland, M. Signals from the underground: Bacterial volatiles promote growth in Arabidopsis. Trends Plant Sci. 2004, 9, 263-266. [CrossRef] [PubMed]

50. Takei, K.; Sakakibara, H.; Taniguchi, M.; Sugiyama, T. Nitrogen-dependent accumulation of cytokinins in root and the translocation to leaf: Implication of cytokinin species that induces gene expression of maize response regulator. Plant Cell Physiol. 2001, 42, 85-93. [CrossRef] [PubMed]

51. García de Salamone, I.E.; Hynes, R.K.; Nelson, L.M. Cytokinin production by plant growth promoting rhizobacteria and selected mutants. Can. J. Microbiol. 2001, 47, 404-411. [CrossRef]

52. Vavrina, C.S. An Introduction to the Production of Containerized Vegetable Transplants; University of Florida, Institute of Food and Agricultural Sciences: Gainesville, FL, USA, 1996; Volume 302.

53. Gurska, J.; Wang, W.; Gerhardt, K.E.; Khalid, A.M.; Isherwood, D.M.; Huang, X.-D.; Glick, B.R.; Greenberg, B.M. Three Year Field Test of a Plant Growth Promoting Rhizobacteria Enhanced Phytoremediation System at a Land Farm for Treatment of Hydrocarbon Waste. Env. Sci. Technol. 2009, 43, 4472-4479. [CrossRef]

54. Stefan, M.; Munteanu, N.; Stoleru, V.; Mihasan, M. Effects of inoculation with plant growth promoting rhizobacteria on photosynthesis, antioxidant status and yield of runner bean. Rom. Biotechnol. Lett. 2013, $18,8132-8143$.

55. Stefan, M.; Munteanu, N.; Stoleru, V.; Mihasan, M.; Hritcu, L. Seed inoculation with plant growth promoting rhizobacteria enhances photosynthesis and yield of runner bean (Phaseolus coccineus L.). Sci. Hortic. 2013, 151, 22-29. [CrossRef]

56. Han, H.S.; Lee, K.D. Plant growth promoting rhizobacteria effect on antioxidant status, photosynthesis, mineral uptake and growth of lettuce under soil salinity. Res. J. Agric Biol. Sci. 2005, 1, $210-215$.

57. Baset, M.; Shamsuddin, Z.H.; Wahab, Z.; Marziah, M. Effect of plant growth promoting rhizobacterial (PGPR) inoculation on growth and nitrogen incorporation of tissue-cultured'musa'plantlets under nitrogen-free hydroponics condition. Aust. J. Crop Sci. 2010, 4, 85.

58. Ihl, M.; Shene, C.; Scheuermann, E.; Bifani, V. Correlation for pigment content through colour determination using tristimulus values in a green leafy vegetable, swiss chard. J. Sci. Food Agric. 1994, 66, 527-531. [CrossRef]

59. Madeira, A.C.; Ferreira, A.; De Varennes, A.; Vieira, M.I. SPAD Meter Versus Tristimulus Colorimeter to Estimate Chlorophyll Content and Leaf Color in Sweet Pepper. Commun. Soil Sci. Plant Anal. 2003, 34, 2461-2470. [CrossRef]

60. Ciardi, J.A.; Vavrina, C.S.; Orzolek, M.D. Evaluation of tomato transplant production methods for improving establishment rates. HortScience 1998, 33, 229-232. 
61. European Commission Commission regulation (EU) No 1258/2011 of 2 December 2011 amending Regulation (EC) No 1881/2006 as regards maximum levels for nitrates in foodstuffs. Off. J. Eur. Union 2011, L 320/15, $15-17$.

62. Balanza, V.; Martinez, J.; Conesa, E.; Egea-Gilabert, C.; Niñirola, D.; López-Marín, J.; Gonzalez, A.; Fernández, J.A. Effect of PGPR application and nitrogen doses on baby leaf lettuce grown in a floating system. Acta Hortic. 2012, 952, 679-687. [CrossRef]

63. Song, X.; Liu, M.; Wu, D.; Griffiths, B.S.; Jiao, J.; Li, H.; Hu, F. Interaction matters: Synergy between vermicompost and PGPR agents improves soil quality, crop quality and crop yield in the field. Appl. Soil Ecol. 2015, 89, 25-34. [CrossRef]

64. Kavino, M.; Harish, S.; Kumar, N.; Saravanakumar, D.; Samiyappan, R. Effect of chitinolytic PGPR on growth, yield and physiological attributes of banana (Musa spp.) under field conditions. Appl. Soil Ecol. 2010, 45, 71-77. [CrossRef]

65. Zhang, M.; Liu, M.; Zhang, Y.; Ji, Y.; Zhao, M.; Wu, Z. Effect of different plant growth regulator added in nutrient solution on growth and development of summer tomato seedling. North Hortic 2017, 6, 8-13.

66. Khan, N.A. Effect of gibberellic acid on carbonic anhydrase, photosynthesis, growth and yield of mustard. Boil. Plant. 1996, 38, 145. [CrossRef]

67. Miceli, A.; Moncada, A.; Sabatino, L.; Vetrano, F. Effect of Gibberellic Acid on Growth, Yield, and Quality of Leaf Lettuce and Rocket Grown in a Floating System. Agronomy 2019, 9, 382. [CrossRef]

68. Khan, N.A.; Mir, R.; Javid, S. Samiullah Effects of gibberellic acid spray on nitrogen yield efficiency of mustard grown with different nitrogen levels. Plant Growth Regul. 2002, 38, 243-247. [CrossRef]

69. Miceli, A.; Vetrano, F.; Sabatino, L.; D’Anna, F.; Moncada, A. Influence of Preharvest Gibberellic Acid Treatments on Postharvest Quality of Minimally Processed Leaf Lettuce and Rocket. Horticulturae 2019, 5, 63. [CrossRef]

70. Vetrano, F.; Moncada, A.; Miceli, A. Use of Gibberellic Acid to Increase the Salt Tolerance of Leaf Lettuce and Rocket Grown in a Floating System. Agronomy 2020, 10, 505. [CrossRef]

(C) 2020 by the authors. Licensee MDPI, Basel, Switzerland. This article is an open access article distributed under the terms and conditions of the Creative Commons Attribution (CC BY) license (http://creativecommons.org/licenses/by/4.0/). 